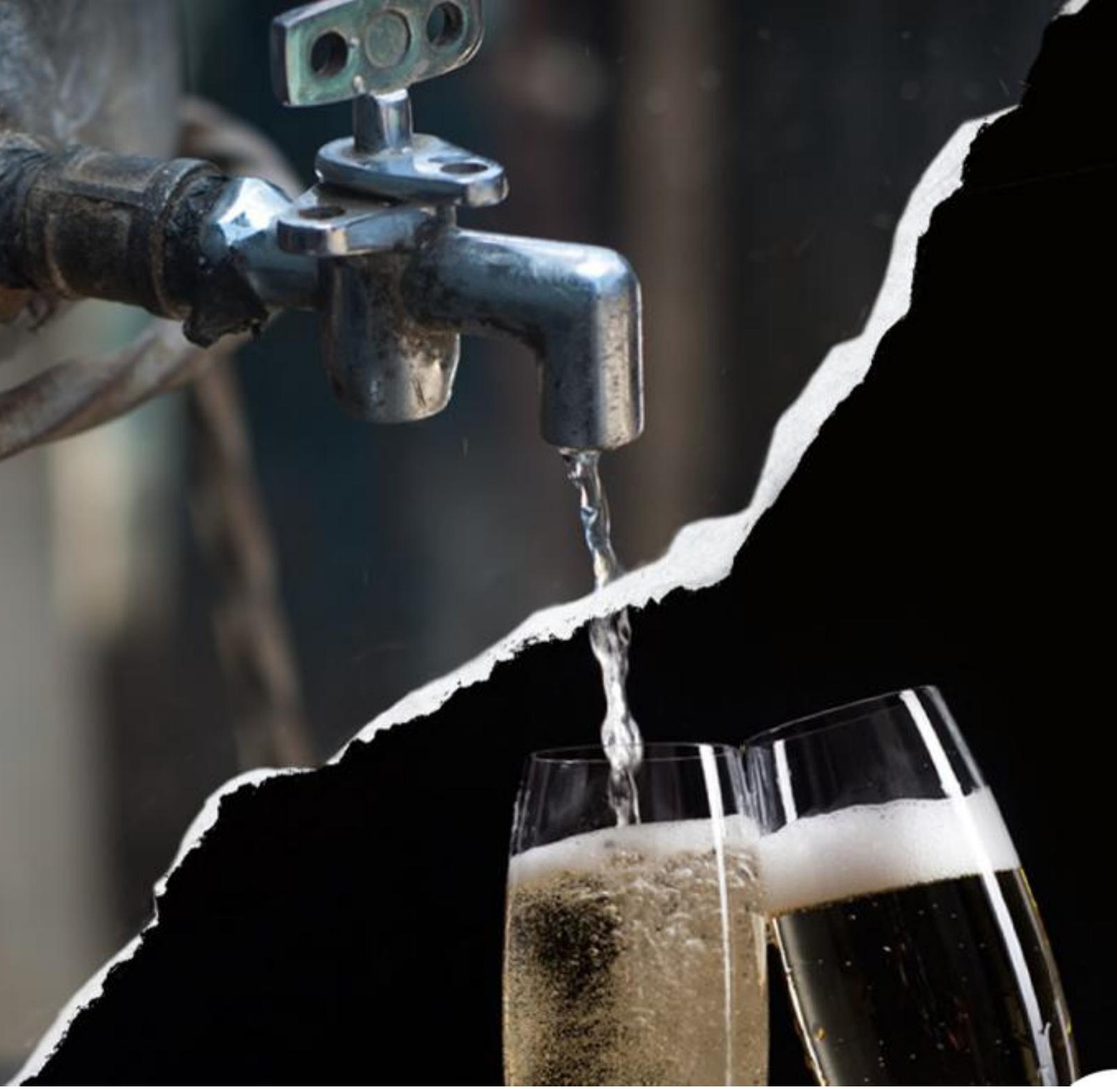

\title{
THE USE OF TAX HAVENS IN THE \\ OWNERSHIP OF RENYAN PETROLEUM RIGHTS
}

\section{Don Hubert, PhD}

Resources for Development Consulting

May 2016

www.oxfam.org

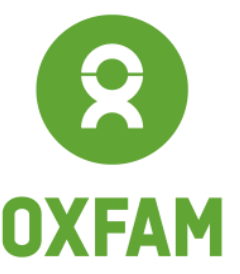


Oxfam Research Reports are written to share research results, to contribute to public debate and to invite feedback on development and humanitarian policy and practice. They do not necessarily reflect $0 x f a m$ policy positions. The views expressed are those of the author and not necessarily those of Oxfam.

\section{For more information on this report, email the Tax Justice Programme Manager on wkinyori@oxfam.org,uk}

(C) Oxfam International May 2016

The text may be used free of charge for the purposes of advocacy, campaigning, education, and research, provided that the source is acknowledged in full. The copyright holder requests that all such use be registered with them for impact assessment purposes. For copying in any other circumstances, or for re-use in other publications, or for translation or adaptation, permission must be secured and a fee may be charged. E-mail policyandpractice@oxfam.org.uk

Published by Oxfam GB for Oxfam International in May 2016. Oxfam GB, Oxfam House, John Smith Drive, Cowley, Oxford, OX4 2JY, UK.

Oxfam GB is a registered charity in England and Wales (no 202918) and Scotland (SC039042).

Oxfam GB is a member of Oxfam International. 
Table of Contents

INTRODUCTION ....................................................................................................... 4

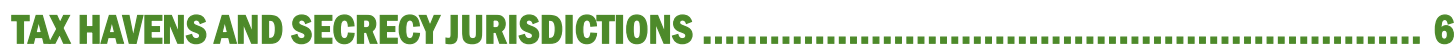

COUNTRIES APPEARING ON VARIOUS TAX HAVEN LISTS .......................................... 7

THE ALLOCATION OF PETROLEUM RIGHTS ................................................................. 9

THE TRANSFER OF PETROLEUM RIGHTS .................................................................11

CURRENT STATUS OF KENYAN PETROLEUM RIGHTS................................................12

CORPORATE STRUCTURES AND TAX HAVENS .........................................................17

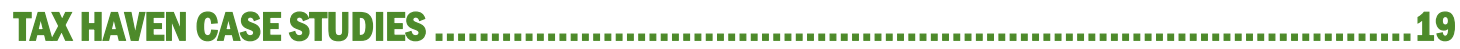

NOTES .................................................................................................................31 


\section{INTRODUCTION}

As an emerging petroleum producer, Kenya has the opportunity to reap the benefits of its natural resource wealth to further economic and human development. Many of the key factors that will determine the amount of potential government revenue from Kenya's petroleum wealth fall outside of the government's control. The most important of these are the volume of commercially recoverable oil in the country and the price for that oil when it reaches international markets. The main factor within the governments' control is the set of fiscal (tax) terms offered to international oil companies to explore for new sources of oil and natural gas.

These fiscal terms are set out in a series of production sharing contracts that the government has signed with international oil companies. The fiscal terms establish the broad framework that determine how much of the divisible, or "after cost", revenue will be allocated to the company and how much will be allocated to the government. During the exploration phase, the interest of the companies and the government are broadly aligned both sides are hoping that exploration success can be rapidly converted into large-scale petroleum production. Once production begins, however, tensions between the parties can arise as both sides seek to maximize their share of project revenues.

There is growing concern among resource-rich developing countries in Africa and beyond that companies are employing aggressive tax avoidance strategies in order to increase their share of divisible revenue. ${ }^{1}$ There are a number of potential mechanisms through which companies seek to minimize their revenue payments to governments. One specific area of concern is the use of subsidiaries registered in tax havens.

Multinationals have increasingly organized their corporate structures around tax havens and low tax jurisdiction in order to take advantage of international loopholes. ${ }^{2}$ Tax havens provide the attractive combination of zero or very low tax rates combined with high levels of secrecy. Creating "conduit" subsidiary companies in between the productive company overseas and the parent company at home allows companies to shift both profits and costs and in the process significantly reduce tax payments. While developing countries have complained about these practices for many years, following the recent economic crisis, developed countries have now recognized that they too are losing vast amounts of potential tax revenue. ${ }^{3}$

The problem is particularly acute in the extractive sector, where large multi-national companies establish complex corporate structures in order to minimize tax payments and maximize profits. Research on the $\mathbf{1 0}$ largest extractive sector companies in the world demonstrates that they control over 6,000 subsidiaries of which more than a third were located in tax havens or secrecy jurisdictions. ${ }^{4}$ Zambia provides a concrete example where billions of dollars in revenue were lost due to copper being sold on paper to a subsidiary of Glencore registered in the low-tax jurisdiction of Switzerland. ${ }^{5}$

The first step in analyzing the potential for government revenue loss due to tax havens is to understand the corporate structures of the companies that hold petroleum rights in Kenya. This paper therefore analyzes the initial allocation and subsequent transfer of rights to the 41 petroleum blocks currently licensed to international oil companies. Having identified the 
thirty-five companies that directly hold Kenyan petroleum rights, we then map their corporate structures through various subsidiaries through to the ultimate parent company.

Unfortunately, the Government of Kenya provides relatively little information on the ownership of petroleum rights. International best practice in extractive sector governance recommends disclosure of corporate structures and beneficial (ultimate) owners of extractive sector rights. However, the government of Kenya provides little more than an outdated map showing petroleum Blocks, along with an imprecise name of leading companies.

The data complied in this report has been drawn from company documents that are public domain information including annual reports, press releases, and, most importantly, corporate filings provided to investors as required by stock exchange authorities. We have also drawn on publicly accessible corporate registries, including the consolidation of corporate information provided by Open Corporates. ${ }^{6}$ While there may be some minor gaps, where company information was incomplete or inconsistent, we believe that the data included in this report provides a comprehensive ovewiew of the holders of petroleum rights in Kenya.

This analysis reveals the widespread use of tax havens and low tax jurisdictions in the corporate structures of companies holding petroleum rights in Kenya. In total, thirty-five separate companies hold a percentage stake in at least one of the 41 active petroleum license in Kenya. These subsidiaries are ultimately owned by twenty-seven separate parent companies. Seventeen of these parent companies own petroleum rights in Kenya directly through a subsidiary registered in a tax haven. Ultimately, all but five of the parent companies make use of a tax haven or low-tax jurisdiction as part of their wide corporate structure. 


\section{TAX HAVENS AND SECRECY JURISDICTIONS}

There is no single agreed definition of what constitutes a tax haven. The first formal definition came from the Organization for Economic Cooperation and Development (OECD) in the late $1990 \mathrm{~s}^{7}$. Since that time definitions, and corresponding lists, have been generated by multiple organizations including the IMF, the European Union, the United State Government, as well as the Tax Justice Network.

The original OECD analysis was based on a four-part definition including: no or low effective tax rate; ring-fencing where preferential tax regimes are insulated from the domestic economy; lack of transparency involving inadequate regulatory supervision and financial disclosure; and lack of effective exchange of information. ${ }^{8}$ The IMF adopts a similar threepart definition for offshore financial centres (OFCs) including: a primary orientation of business towards non-residents; a favorable regulatory environment (low supervisory requirements and minimal information disclosure); and low or zero taxation schemes ${ }^{9}$.

More recently, emphasis has shifted more towards tax cooperation and secrecy as the defining feature of tax havens. The OECD now focuses exclusively on a declining number of what it calls "non-cooperative" jurisdictions ${ }^{10}$. For civil society, while a "zero or low tax rate" continues to be a defining feature, secrecy has become the more prominent focus. The Tax Justice Network, for example, considers the essence of tax havens to revolve around two inter-related kinds of secrecy: 11

1. strong bank secrecy: information can not be obtained from banks and other financial institutions for official purposes such as tax collection;

2. secrecy of legal entities: information is not available or obtainable about companies, corporations, trusts, foundations, or other legal entities, such as the beneficial owners, details of persons with power to determine the use of assets, or financial accounts.

Lists of tax havens and/or offshore financial centres have been compiled by various organizations including the OECD, the IMF, the US government, the European Union and the Tax Justice Network (Financial Secrecy Index). Jurisdictions identified as tax havens in these various lists are shown in Annex I. The table below lists jurisdictions that appear on various lists, arranged by geographic location. 


\section{COUNTRIES APPEARING ON VARIOUS TAX HAVEN LISTS}

\begin{tabular}{|l|l|}
\hline Caribbean/West Indies & $\begin{array}{l}\text { Anguilla, Antigua and Barbuda, Aruba, Bahamas, Barbados, } \\
\text { Bermuda, British Virgin Islands, Cayman Islands, Curacao, } \\
\text { Dominica, Grenada, Montserrat, St. Kitts and Nevis, St. Lucia, } \\
\text { St. Vincent and Grenadines, Turks and Caicos, U.S. Virgin } \\
\text { Islands }\end{array}$ \\
\hline Central America & Belize, Costa Rica, Panama \\
\hline East Asia & Hong Kong, Macau, Singapore \\
\hline Europe/Mediterranean & $\begin{array}{l}\text { Andorra, Channel Islands (Guernsey and Jersey), Cyprus, } \\
\text { Gibraltar, Isle of Man, Ireland, Liechtenstein, Luxembourg, } \\
\text { Malta, Monaco, San Marino, Switzerland }\end{array}$ \\
\hline Indian Ocean & Maldives, Mauritius, Seychelles \\
\hline Middle East & Bahrain, Jordan, Lebanon \\
\hline Pacific, South Pacific & $\begin{array}{l}\text { Cook Islands, Marshall Islands, Samoa, Nauru, Niue, Tonga, } \\
\text { Vanuatu }\end{array}$ \\
\hline West Africa & Liberia \\
\hline
\end{tabular}

There are other jurisdictions that offer important tax exemptions or high levels of confidentiality in order to attract financial activity. Foremost among these are the US state of Delaware and the Netherlands. A study of the ten largest extractive sector companies found that the Delaware accounted for the highest number of subsidiaries, with the Netherlands being second ${ }^{12}$.

Delaware is widely acknowledged as having the lowest level of corporate disclosure in the United States ${ }^{13}$. It is one of the reasons why the one million businesses incorporated there outnumber the population of the state. More specifically, company accounts and beneficial ownership details are not maintained in official records, and international regulatory requirements and requests for information sharing are frequently ignored. Delaware also offers tax exemptions including a zero tax on "intangible assets" including patents, copyrights, and brands. As a result of these provisions, US corporations commonly create a Delaware subsidiary between the parent company and overseas investments.

The Netherlands, home of the world's first corporation (the Dutch East India Company) remains a highly attractive location for multinationals to establish subsidiaries. Having concluded tax treaties with 91 countries, routing money through a subsidiary in the Netherlands allows companies to minimize withholding taxes on dividends, interest and royalties. ${ }^{14}$ Multinational companies also commonly use subsidiaries in the Netherlands for shifting internal corporate debt. Known as "conduit" or "mailbox" companies, they are engaged in what is known as "treaty shopping" where a legal entity is created in a specific jurisdiction in order to obtain treaty benefits that would not be available directly. The Netherlands is home to more conduit companies than any other jurisdiction in the world. 
Double Taxation Agreements (DTAs) are the key to the Netherlands' attractiveness as a home for conduit companies. In theory, DTAs were originally designed to avoid companies operating in multiple countries and paying tax on the same income in two jurisdictions. In practice, they are increasingly being used to avoid paying tax altogether. Mongolia has recently terminated a DTA with the Netherlands over concern about revenue loss from their mining sector (See Textbox 1). ${ }^{15}$ The Netherlands has also been implicated in a recent study on the mining sector revenue loss in Malawi. ${ }^{16}$ In July 2015, Kenya signed a Double Taxation Agreement with the Netherlands, providing for zero or reduced rates on withholding taxes on dividends and interest. ${ }^{17}$

Textbox 1: Mongolia Mining Revenues at Risk in the Netherlands

In 2012, Mongolia's Ministry of Finance conducted research into Mongolia's double taxation treaties, specifically comparing the benefits they provide to those offered by peer countries such as the Philippines and Ghana. Their conclusion, supported by the IMF, was that Mongolia could lose billions of dollars in potential mining revenue due to a double taxation treaty signed in $\mathbf{2 0 0 2}$ with the Netherlands. Under this treaty, if a Dutch company invests in Mongolia it is entitled to pay dividends back to the Netherlands free of the normal $20 \%$ Mongolian withholding tax.

The focus of the analysis was a company called Turquoise Hill Resources, which developed the Oyu Tongoi mine, the country's largest project. Although the company is Canadian, it used a subsidiary in the Netherlands (Oyu Tolgoi Netherlands BV) in order to benefit from the double tax treaty. While Turquoise Hill was the most important of the companies, it was not alone. According to the Mongolian authorities, almost $70 \%$ of all foreign direct investment was coming through the Netherlands as a tax shield.

In November 2012, the Mongolian Parliament passed a law to terminate the double taxation treaties with the Netherlands effective 1 January 2014. They also terminated similar agreements with Luxembourg, Kuwait and the UAE. Ultimately, however, ending the agreement with the Netherlands will not impact Turquoise Hill or the Oyu Tongoi mine. A stabilization clause in the contract guarantees that the exemption from the Mongolian withholding tax will continue to exist for the life of the mine. 


\section{THE ALLOCATION OF PETROLEUM RIGHTS}

Kenya allocates rights to explore and produce petroleum through the negotiation of a production sharing contract or PSC. The four potential oil-producing basins have been divided into 46 blocks or concessions.

Petroleum rights have been allocated based on unsolicited applications received from companies. Specifically, the Ministry of Energy and National Oil Corporation of Kenya accept applications from international oil exploration investors for available Blocks. The current process is set out in Figure 1 below. ${ }^{18}$

The petroleum policy of 2013 indicated that future licenses would be allocated according to a competitive bidding process often known as a "licensing round." The competitive process is increasingly seen as part of petroleum sector best practice. It is common for countries to move from an individual application system to a competitive process once commercial quantities of oil have been discovered.

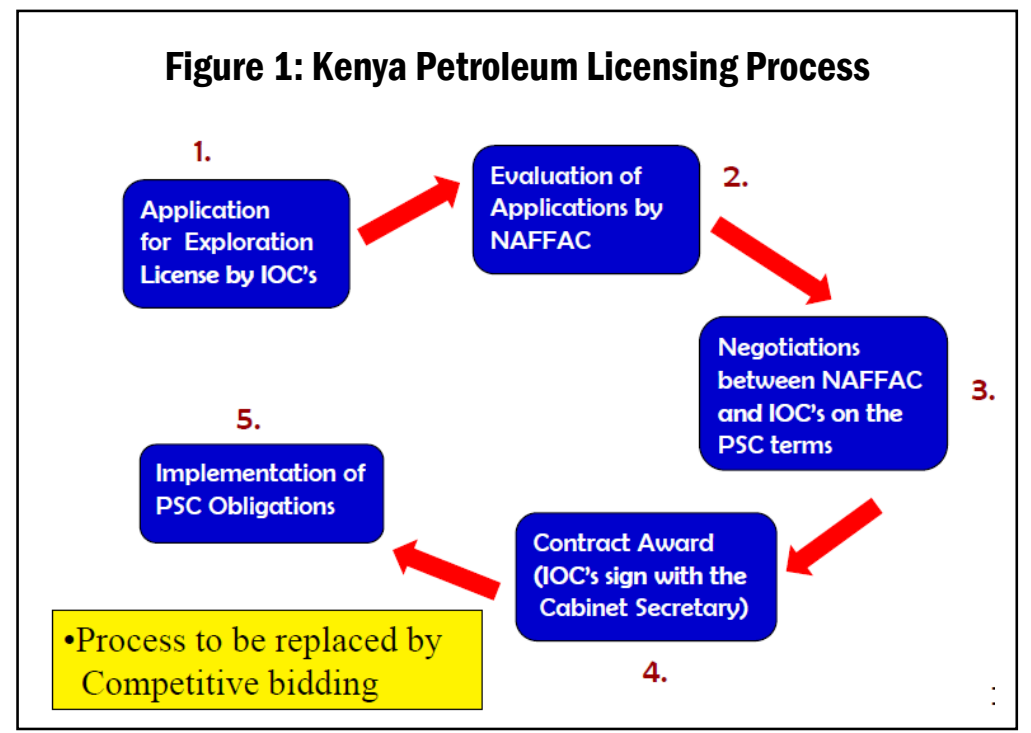

Rights can either be granted to a single company or to a consortium of companies. Where more than one company holds rights to a petroleum concession, the lead company is known as the "operator" while the other companies are known as "joint venture" partners. The operator serves as the overall manager and decision-maker of the project. Generally, though not always, the operator has the largest financial stake in the project. The operator is responsible for paying for the operation and recoups a portion of the expenses from joint venture partners, normally in proportion to their percentage stake in the project.

It is also common for a national oil company to hold an equity stake in the project, though this often happens only after exploration efforts have been successful. In Kenya, the National Oil Corporation of Kenya (NOCK) has the right to a percentage stake in all projects. The size of the stake is negotiable and is set out in the PSC. NOCK does not participate during the exploration phase with all risks falling on the contractor. If exploration efforts are successful, NOCK has the right to acquire or "back-in" to the percentage stake as set out in the PSC. This is reportedly the case for Blocks 10BB and 13T. The one exception to the approach described above is Block $14 \mathrm{~T}$ where NOCK holds the exclusive rights and is therefore solely responsible for exploration efforts in that area.

The Table below provides a comprehensive list based on public domain sources of the active production sharing contracts, including the lead signatory and the effective date. 
Kenyan Petroleum Blocks \& Production Sharing Contracts

\begin{tabular}{|c|c|c|c|c|c|}
\hline Block & Lead Signatory & Date & Block & Lead Signatory & Date \\
\hline 1 & Lion Petroleum Corp & $11 / 19 / 2007$ & L-08 & Relinquished & \\
\hline $02 \mathrm{~A}$ & Simba Africa Rift Energy Limited & $8 / 3 / 2011$ & L-09 & Dominion Petroleum Kenya Limited & $5 / 1 / 2011$ \\
\hline O2B & Lion Petroleum Corp. & $9 / 17 / 2008$ & L-10A & BG Kenya L10A Limited & $5 / 17 / 2011$ \\
\hline 03A & Avana Petroleum Kenya Ltd. & $10 / 1 / 2007$ & L-10B & BG Kenya L10B Limited & $5 / 17 / 2011$ \\
\hline 03B & Avana Petroleum Kenya Ltd. & $10 / 1 / 2007$ & $L-11 A$ & Anardarko Kenya Company & $6 / 28 / 2009$ \\
\hline 09 & CNOOC Africa Limited & $4 / 1 / 2006$ & L-11B & Anardarko Kenya Company & $6 / 28 / 2009$ \\
\hline $10 \mathrm{~A}$ & Relinquished & & L-12 & Anardarko Kenya Company & $6 / 28 / 2009$ \\
\hline 10BA & Centric Energy (Kenya) Limited & $1 / 27 / 2010$ & L-13 & SOHI Oil \& Gas Ltd & $9 / 3 / 2008$ \\
\hline 10BB & Turkana Drilling Consortium (Kenya) Limited & $10 / 25 / 2007$ & L-14 & Lamu Oil \& Gas Limited & $7 / 1 / 2012$ \\
\hline $11 \mathrm{~A}$ & ERHC AGC Profond Ltd. & $6 / 1 / 2012$ & $\mathrm{~L}-15$ & Relinquished & \\
\hline $11 \mathrm{~B}$ & Adamantine Energy (Kenya) Limited & $6 / 1 / 2012$ & L-16 & CAMAC Energy Kenya Limited & $5 / 10 / 2012$ \\
\hline $12 \mathrm{~A}$ & Platform Resources Inc. & $9 / 17 / 2008$ & L-17 & Black Marlin Energy Ltd. & $10 / 7 / 2010$ \\
\hline 12B & Tullow Kenya B.V & $2 / 16 / 2012$ & L-18 & Black Marlin Energy Ltd & $10 / 7 / 2010$ \\
\hline $13 \mathrm{~T}$ & Platform Resources Inc. & $9 / 17 / 2008$ & $\mathrm{~L}-19$ & Rift Energy Corp. & $6 / 1 / 2012$ \\
\hline $14 \mathrm{~T}$ & National Oil Corporation of Kenya & $11 / 1 / 2010$ & $L-20$ & Pacific Seaboard Investment Ltd. & $6 / 1 / 2012$ \\
\hline L-01A & A-Z Petroleum (Kenya) Limited & 2011 & L-21 & ENI Kenya B.V. & $7 / 2 / 2012$ \\
\hline$L-01 B$ & CAMAC Energy Kenya Limited & $5 / 1 / 2012$ & $\mathrm{~L}-22$ & Total E\&P Kenya B.V. & $7 / 1 / 2012$ \\
\hline $\mathrm{L}-02$ & Imara Energy Corp. & $24 / 05 / 2012$ & $L-23$ & ENI Kenya B.V. & $7 / 2 / 2012$ \\
\hline L-03 & A-Z Petroleum (Kenya) Limited & 2011 & L-24 & ENI Kenya B.V. & $7 / 2 / 2012$ \\
\hline L-04 & SOHI Oil \& Gas Ltd & $9 / 3 / 2008$ & $\mathrm{~L}-25$ & Relinquished & \\
\hline L-05 & Anardarko Kenya Company & $6 / 28 / 2009$ & $L-26$ & Relinquished & \\
\hline L-06 & Flow Energy Limited & $18 / 03 / 2011$ & L-27 & CAMAC Energy Kenya Limited & $5 / 1 / 2012$ \\
\hline L-07 & Anardarko Kenya Company Limited & $6 / 28 / 2009$ & L-28 & CAMAC Energy Kenya Limited & $5 / 1 / 2012$ \\
\hline
\end{tabular}




\section{THE TRANSFER OF PETROLEUM RIGHTS}

The initial allocation of petroleum rights often bears little relation to the companies that subsequently hold those rights. In some case, the original rights holders agree to sell to other companies. The transfer then takes place following the approval of the Ministry of Energy and Petroleum (MEP). This happened, for example, in the case of the two most significant petroleum Blocks in the country - 10BB and 13T.

In October 2007, a Kenyan company named Turkana Drilling Consortium Kenya Limited (a wholly owned subsidiary of Canadian registered Turkana Energy) signed a PSC for Block 10BB. In 2009, the Canadian registered Africa Oil Corp. purchased Turkana Energy. Following approval from MEP, the Kenyan subsidiary was renamed Africa Oil Turkana Limited. ${ }^{19}$

In September 2008, a Canadian company named Platform Resources Inc. (a wholly owned subsidiary of the Canadian company Alberta Oil Sands Inc.) signed a PSC for Block 13T. In September 2010, Canadian company Africa Oil Corp. bought the rights to Blocks 12A and 13T held by Platform Resources. Following approval of the transaction from the MEP, the rights were transferred to an Africa Oil Corp. subsidiary named Africa Oil Kenya B.V. registered in the Netherlands. ${ }^{20}$

In other cases, the company holding the rights sells off a percentage stake to other joint venture partners. This process, known in the industry as a "farm-down," is often used to bring in additional technical and financial resources in order to meet minimum exploration commitments set out in the PSC. Once again, the process can be seen in the transfer of rights to Blocks 10BB and 13T.

In February 2011, Africa Oil Corporation sold a $50 \%$ stake of their rights to five Kenyan Blocks including 10BB and 13T to Tullow Oil PIc, an Irish company registered in the UK. Following the approval of the MEP, the $\mathbf{5 0 \%}$ stake in the respective Blocks was transferred to a Tullow subsidiary named Tullow Kenya B.V. registered in the Netherlands. ${ }^{21}$

In January 2016, Africa 0il Corp sold a further 25\% stake in three Blocks (including $10 B B$ and 13T) to a Danish company registered in the United Kingdom called Maersk Oil \& Gas A/S. Following the approval of the MEP, the rights were transferred to three separate Maersk subsidiaries also registered in the UK. ${ }^{22}$

Companies can also leave joint ventures, particularly after unsuccessful exploratory drilling. If one company leaves behind other joint venture partners, the stakes are normally reallocated proportionately to those that remain. An example can be seen in Block L-10B.

In May 2011, BG Kenya L-10B Limited (a wholly owned Kenyan subsidiary of BG Group PIc registered in the United Kingdom) signed a PSC as operator for offshore Block L-10B. From the outset, three other companies participated in the joint venture including Premier Oil Investments (25\%), Cove Energy (15\%) and Pancontinental Oil \& Gas (15\%). In April 2015, the last remaining joint venture 
partner Pancontinental Oil and Gas withdrew resulting in BG Kenya L-10B holding the full $100 \%$ stake. ${ }^{23}$

A Block has been "relinquished" when all joint venture partners withdraw. This may happen as a result of unsuccessful exploration or when the exploratory period, as set out in the PSC, expires. Block L-08 offshore provides an example.

In 2006, Origin Kenya Pty Limited (a wholly owned subsidiary of Australianregistered Origin Energy Limited) signed a PSC for offshore Block L-08. Later that year they sold a 25\% stake in the Block to Pancontinental 0il \& Gas. In June 2011, Pancontinental sold a $\mathbf{1 0 \%}$ stake to Tullow Kenya B.V. That same month, Origin Kenya Pty Limited sold a $\mathbf{5 0 \%}$ stake, and the role of operator, to a subsidiary of USregistered Apache Corp. ${ }^{24}$

In 2014, following the discovery of non-commercial volumes of natural gas, Apache withdrew from the Block. Pancontinental engaged in follow-on discussions with the MEP but with no company willing to take over the role of operator, the Block was ultimately relinquished ${ }^{25}$.

Once a Block has been relinquished, it is available for reallocation with the signing of a new PSC.

\section{CURRENT STATUS OF KENYAN PETROLEUM RIGHTS}

Kenya has demarcated a total of 46 petroleum blocks with 41 currently licensed to oil exploration and production companies.

The principal source of information provided by the government is a map of exploration blocks along with a list of the lead company. The most recent Block map provided by NOCK, from December 2014, is shown in Figure 2.

Unfortunately, the map itself is outdated and the information provided is incomplete. Some blocks have been relinquished since this map was published (e.g. 10A, L-08, L-15 and L26). Furthermore, the list of companies includes neither the legal names of the operators or joint venture partners nor information on the size of their respective stakes.

No additional information on the ownership of petroleum appears to be available from either the Ministry of Energy and Petroleum or the National Oil Corporation of Kenya. This is unfortunate as it is now widely accepted that good governance of extractive sector resources requires transparency on the ownership of rights (See Textbox 2). 
Figure 2: Kenya Exploration Blocks - December 2014

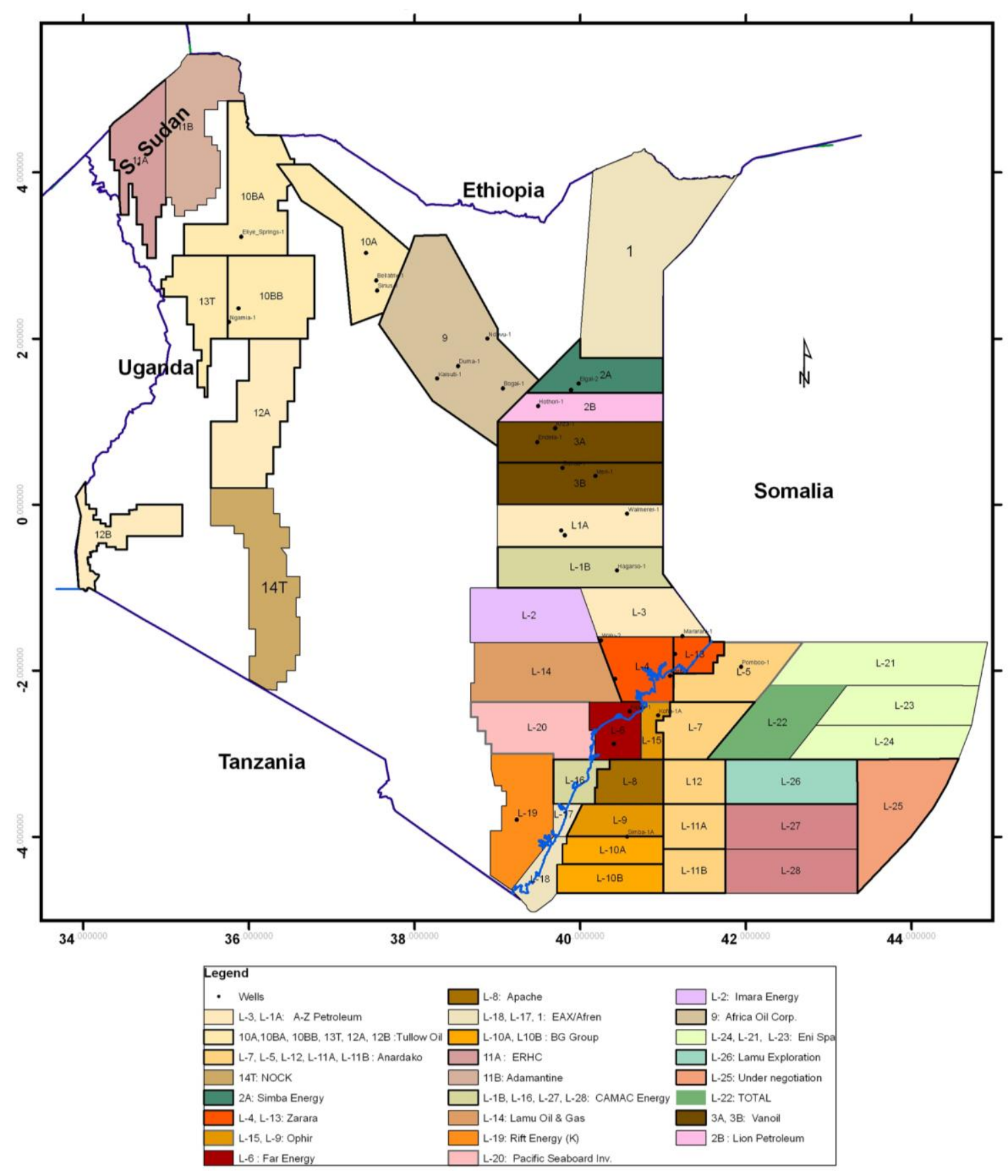




\section{Textbox 2: Transparency on Ownership of Petroleum Rights}

As part of the larger movement for greater transparency in the extractive sector, there is now increased attention focused on the companies that holding rights to oil, gas and mineral concessions. Norway once again sets the "gold standard" for oil sector transparency. The Norwegian Petroleum Directorate publishes "FACTPAGES" providing detailed information on current and past rights holders including the legal names of operators and joint venture partners, and dates when the rights were acquired, sold and relinquished.

A number of other countries provide a public registry of oil companies active in exploration and production including: Argentina (Owners and Operators of Areas), Australia (National Offshore Petroleum Titles Administrator), Brazil (National Agency of Petroleum), Colombia (National Hydrocarbon Agency), Ghana (Ghana National Petroleum Corporation), India (Director General of Hydrocarbons), and Peru (Perupetro).

Several countries have expanded public data portals originally developed for the mining sector to include petroleum concessions (See Liberia, Namibia, Mozambique). Although these provide less information that the public registries, they do allow for public access to up-to-date information on operator and joint venture partners and, in some cases, license start and expiry dates. As Kenya has adopted an online cadastre for the mining sector, this could easily be expanded to include the petroleum sector as well.

The Extractive Industries Transparency Initiative has also extended its focus beyond transparency of revenue payments to ownership of extractive sector rights. The current EITI Standard, agreed in 2013 includes an obligation to maintain a "register of licenses" conferring rights to explore or exploit oil, gas and mineral resources. Disclosure must include the names of the license holders, the coordinates of the license area and the date of award and duration of the license. Disclosure on beneficial ownership (the natural person who directly or indirectly ultimately owns or controls the corporate entity) is recommended.

Although the Kenyan Government provides only limited information on companies holding petroleum rights, most of the companies themselves provide substantial details. This is particularly true for publicly listed companies who are required by stock exchange regulations to report details of the ownership rights of petroleum blocks to their investors.

The Table below has been complied through an exhaustive review of public domain information including corporate filings to all relevant stock exchanges as well as company annual reports and press releases. We believe that this information is up-to-date as of January 2016. However, given the combination of low oil prices and exploration periods for several blocks nearing expiry, there could be some recent changes that have not been included. In particular, several blocks appear to be close to relinquishment and may only be awaiting final government approval. 


\begin{tabular}{|c|c|c|}
\hline Block & Operator & Joint Venture Partners \\
\hline 1 & $\begin{array}{l}\text { East Africa Exploration (Kenya) Ltd } \\
(80 \%)^{26}\end{array}$ & Lion Petroleum Corp. (20\%) \\
\hline $02 \mathrm{~A}$ & Simba Africa Rift Energy Limited (40\%)27 & Essel Group M.E. (60\%) \\
\hline 02B & \multicolumn{2}{|l|}{ Lion Petroleum Corp (100\%) } \\
\hline 03A & \multicolumn{2}{|l|}{ Avana Petroleum Kenya Ltd. $(\mathbf{1 0 0 \%})^{28}$} \\
\hline 03B & \multicolumn{2}{|l|}{ Avana Petroleum Kenya Ltd. $(\mathbf{1 0 0} \%)^{29}$} \\
\hline 9 & Africa Oil Turkana Ltd (50\%) ${ }^{30}$ & Marathon Kenya Limited BV (50\%) \\
\hline 10A & \multicolumn{2}{|l|}{ Unallocated Block } \\
\hline \multirow[b]{2}{*}{ 10BA } & \multirow[t]{2}{*}{ Tullow Kenya BV (50\%) 31} & Centric Energy (Kenya) Ltd (25\%) ${ }^{32}$ \\
\hline & & $\begin{array}{l}\text { Maersk Oil Exploration International } \\
\text { K1Limited }(25 \%)^{33}\end{array}$ \\
\hline \multirow[b]{2}{*}{ 10BB } & \multirow[t]{2}{*}{ Tullow Kenya BV (50\%) 34} & Africa Oil Turkana Ltd (25\%) ${ }^{35}$ \\
\hline & & $\begin{array}{l}\text { Maersk Oil Exploration International K2 } \\
\text { Limited }(25 \%)^{36}\end{array}$ \\
\hline $11 \mathrm{~A}$ & CEPSA Kenya Ltd $(60.5 \%)^{37}$ & ERHC Energy Kenya Limited (38.5\%) ${ }^{38}$ \\
\hline 11B & Adamantine Energy (Kenya) Limited (50\%) & Bowleven (Kenya) Limited (50\%) ${ }^{39}$ \\
\hline \multirow{3}{*}{$12 A$} & \multirow[t]{3}{*}{ Tullow Kenya BV (40\%) 40} & Africa Oil Kenya BV (20\%) ${ }^{41}$ \\
\hline & & Delonex Energy Ltd. $(25 \%)^{42}$ \\
\hline & & \begin{tabular}{|l} 
Marathon Kenya Limited BV $(15 \%)^{43}$ \\
\end{tabular} \\
\hline 12B & Tullow Kenya BV (50\%) ${ }^{44}$ & Swala Energy Kenya Ltd $(\mathbf{5 0} \%)^{45}$ \\
\hline \multirow[b]{2}{*}{ 13T } & \multirow[t]{2}{*}{ Tullow Kenya BV (50\%) 46} & Africa Oil Kenya BV (25\%) ${ }^{47}$ \\
\hline & & $\begin{array}{l}\text { Maersk Oil Exploration International K3 } \\
\text { Limited }(25 \%)^{48}\end{array}$ \\
\hline L-01A & \multicolumn{2}{|l|}{ A-Z Petroleum (Kenya) Limited $(100 \%)^{49}$} \\
\hline L-01B & \multicolumn{2}{|l|}{ CAMAC Energy Kenya Limited (100\%)50 } \\
\hline L-02 & \multicolumn{2}{|l|}{ Imara Energy Corp. (100\%)51 } \\
\hline L-03 & \multicolumn{2}{|l|}{ A-Z Petroleum (Kenya) Limited (100\%) 52} \\
\hline L-04 & Zarara Oil \& Gas Ltd (82.5\%) ${ }^{53}$ & Sohi Gas Lamu Ltd (16.5\%) 54 \\
\hline \multirow{2}{*}{ L-05 } & \multirow[t]{2}{*}{ Anardarko Kenya Company (50\%) 55} & Total E\&P Kenya BV (40\%)56 \\
\hline & & Cove Energy Kenya Limited $(10.0 \%)^{57}$ \\
\hline L-06 (on) & Milio E\&P (Kenya) Ltd (69.6\%) 58 & Far Limited (30.4\%) 59 \\
\hline L-06 (off) & \multicolumn{2}{|l|}{ Flow Energy Limited (100\%) ${ }^{60}$} \\
\hline \multirow{2}{*}{ L-07 } & \multirow[t]{2}{*}{ Anardarko Kenya Company (50\%) 61} & Total E\&P Kenya BV (40\%) \\
\hline & & Cove Energy Kenya Limited (10.0\%) \\
\hline L-08 & \multicolumn{2}{|l|}{ Unallocated Block } \\
\hline
\end{tabular}




\begin{tabular}{|c|c|c|}
\hline Block & Operator & Jolnt Venture Partners \\
\hline L-09 & \multicolumn{2}{|c|}{ Dominion Petroleum Kenya Limited (100\%) 62} \\
\hline L-10A & \multicolumn{2}{|l|}{ BG Kenya Limited (100\%) ${ }^{63}$} \\
\hline L-10B & \multicolumn{2}{|l|}{ BG Kenya Limited (100\%) ${ }^{64}$} \\
\hline \multirow{3}{*}{ L-11A } & \multirow[t]{3}{*}{ Anardarko Kenya Company (50\%) ${ }^{65}$} & Total E\&P Kenya BV (30\%) \\
\hline & & Cove Energy Kenya Limited (10.0\%) \\
\hline & & Eni (10\%) \\
\hline \multirow{3}{*}{ L-11B } & \multirow[t]{3}{*}{ Anardarko Kenya Company (50\%)66 } & Total E\&P Kenya BV (30\%) \\
\hline & & Cove Energy Kenya Limited (10.0\%) \\
\hline & & Eni Kenya BV (10\%) \\
\hline \multirow{3}{*}{ L-12 } & \multirow[t]{3}{*}{ Anardarko Kenya Company (50\%) ${ }^{67}$} & Total E\&P Kenya BV (30\%) \\
\hline & & Cove Energy Kenya Limited (10.0\%) \\
\hline & & Eni Kenya BV (10\%) \\
\hline L-13 & Zarara 0il \& Gas Ltd 68 & Sohi Gas Dodori Ltd (16.5\%) \\
\hline L-14 & \multicolumn{2}{|l|}{ Lamu 0il \& Gas Limited (100\%)69 } \\
\hline L-15 & \multicolumn{2}{|l|}{ Unallocated Block } \\
\hline L-16 & \multicolumn{2}{|l|}{ CAMAC Energy Kenya Limited $(\mathbf{1 0 0} \%)^{70}$} \\
\hline L-17 & \multicolumn{2}{|c|}{ East Africa Exploration (Kenya) Ltd (100\%) ${ }^{71}$} \\
\hline L-18 & \multicolumn{2}{|l|}{ East Africa Exploration (Kenya) Ltd (100\%) ${ }^{72}$} \\
\hline L-19 & \multicolumn{2}{|l|}{ Rift Energy Corp (100\%) ${ }^{73}$} \\
\hline L-20 & $\begin{array}{l}\text { Milio Exploration \& Production (Kenya) } \\
\text { Ltd }^{74}(\mathbf{9 1 . 8 \% )}\end{array}$ & Pacific Seaboard Investment Ltd. $(\mathbf{8 . 2} \%)^{75}$ \\
\hline L-21 & \multicolumn{2}{|l|}{ ENI Kenya BV $(100 \%)^{76}$} \\
\hline L-22 & \multicolumn{2}{|l|}{ Total E\&P Kenya BV (100\%) 77} \\
\hline L-23 & \multicolumn{2}{|l|}{ ENI Kenya BV $(100 \%)^{78}$} \\
\hline L-24 & \multicolumn{2}{|l|}{ ENI Kenya BV $(100 \%)^{79}$} \\
\hline L-25 & \multicolumn{2}{|l|}{ Unallocated Block } \\
\hline L-26 & \multicolumn{2}{|l|}{ Unallocated Block } \\
\hline L-27 & \multicolumn{2}{|l|}{ CAMAC Energy Kenya Limited (100\%) ${ }^{80}$} \\
\hline L-28 & \multicolumn{2}{|l|}{ CAMAC Energy Kenya Limited (100\%) $)^{81}$} \\
\hline
\end{tabular}




\section{CORPORATE STRUCTURES AND TAX HAVENS}

As the data above shows, as of January 2016, public domain information indicates that there are thirty-five separate companies (either operators or joint venture partners) that hold a stake in at least one of the active petroleum Blocks in Kenya.

We have reviewed the current corporate structures of each of these companies in order to identify both the ultimate parent company as well as any intervening subsidiaries. The full data is shown in Annex II.

In several cases, multiple rights holding subsidiaries are owned by a single parent company. In total then, there are twenty-seven parent companies that hold petroleum rights in Kenya.

Seventeen parent companies use a subsidiary in a tax haven as part of the ownership chain leading directly to petroleum rights in Kenya. Below is a list of the parent company as well as the specific tax haven used in their corporate structure.

\begin{tabular}{|c|c|}
\hline Company Name & Tax Haven \\
\hline Africa Oil Corp. & Barbados, Netherlands ${ }^{82}$ \\
\hline Anadarko Petroleum Corp. & Delaware $^{83}$ \\
\hline Camac International Corp. & Cayman Islands, Delaware $^{84}$ \\
\hline Eni SpA & Netherlands $^{85}$ \\
\hline ERHC Energy Inc & British Virgin Islands $^{86}$ \\
\hline Marathon Oil Corp. & Delaware 87 \\
\hline Midway Resources International & Mauritius 88 \\
\hline Milio International Ltd & Bahamas $^{89}$ \\
\hline Octant Energy Corp. & British Virgin Islands $^{90}$ \\
\hline Ophir Energy PIc & Bermuda $^{91}$ \\
\hline PTT Public Company Limited & Cayman Islands $^{92}$ \\
\hline Rift Energy Corp. & Bermuda $^{93}$ \\
\hline Swiss0il Holdings International Ltd & Mauritius $^{94}$ \\
\hline Swala Energy Ltd & British Virgin Islands $^{95}$ \\
\hline Total S.A. & Netherlands $^{96}$ \\
\hline Tullow Oil PIc & Netherlands $^{97}$ \\
\hline Vanoil Energy Limited & British Virgin Islands \& Isle of Man ${ }^{98}$ \\
\hline
\end{tabular}

The list above includes only cases where there is documentary proof that subsidiaries incorporated in tax havens and low tax jurisdictions are directly part of the ownership chain of Kenyan petroleum rights. There are other ways, however, in which tax havens can be used. For example, Ophir Energy holds petroleum rights in both Kenya and Tanzania. In support of its Tanzania operations, the company used two subsidiaries - Ophir Ventures (Jersey) Limited and Ophir Ventures (Jersey) No. 2 Limited - in the tax haven of Jersey to transfer $\$ 876.4$ million through a "cash box" arrangement. 99 "This can be a way that companies structure their affairs with the risk of minimizing tax payments. " 100 
Below we list additional tax havens, not mentioned above, that are used within the wider corporate family of parent companies that hold petroleum rights in Kenya.

\begin{tabular}{|l|l|}
\hline Company Name & Tax Haven \\
\hline Africa Oil Corp. & Bermuda \\
\hline Anadarko Petroleum Corp. & Bahamas, Cayman Islands \\
\hline BG Group PIc & Cayman Islands \\
\hline Bowleven Limited & British Virgin Islands \\
\hline Compania Espanola De & Panama, Gibraltar, Cyprus, Jersey \\
\hline ENI SpA & Bahamas, Barbados, British Virgin Islands, Luxembourg \\
\hline Essel Group India & Mauritius \\
\hline EDGO Ltd & Mauritius \\
\hline Maersk A/S & $\begin{array}{l}\text { Bahamas, Bermuda, Mauritius, British Virgin Islands, } \\
\text { Vanuatu }\end{array}$ \\
\hline Marathon Oil Corp. & Jersey \\
\hline Milio International & Jersey \\
\hline Ophir Energy PIc & Jersey \\
\hline PTT Public Company Limited & Cyprus \\
\hline Total S.A. & Bermuda, Bahamas, Cayman Islands, Luxembourg, Malta \\
\hline Tullow Kenya BV & British Virgin Islands, Guernsey, Isle of Man, Jersey \\
\hline Taipan Resources Inc & Bahamas \\
\hline Vanoil Energy Ltd. & Mauritius, Isles of Man, British Virgin Islands \\
\hline
\end{tabular}

The overwhelming majority of the companies that hold rights to petroleum blocks in Kenya have at least one subsidiary listed in a tax haven or low tax jurisdiction. In fact, only five companies listed below appear not to make use of tax havens or low-tax jurisdictions as part of their corporate structures.

\begin{tabular}{|l|l|}
\hline Company Name & Jurisdiction \\
\hline Adamantine Energy LLC & Colorado \\
\hline Far Limited & Australia $^{1}$ \\
\hline First Oil PIc & United Kingdom $^{1}$ \\
\hline Qatar First Bank LLC & Qatar $^{1}$ \\
\hline Simba Energy Inc & Canada $^{1}$ \\
\hline
\end{tabular}

The data on corporate ownership set out above is drawn directly from company reports, stock exchange filings for investors and government corporate registries. There are however some gaps in public domain information on ownership of petroleum rights. While publicly listed companies are required by stock exchanges to report details of their ownership rights, some companies have large and diverse portfolios and provide only limited information on specific ventures. Anardarko Petroleum Corp and Compañía Española de Petróleos, S.A.U., for example, disclose limited information on their corporate ownership of petroleum rights in Kenya. Both companies acknowledge that they have subsidiaries holding Kenyan 
petroleum rights (Andarko Kenya Company \& CEPSA Kenya Ltd), but they provide no detail on how these specific subsidiaries fit into their wider corporate structures. There are also some gaps related to smaller, non-listed companies such as SwissOil Holdings International Ltd that lack either websites or public annual reports.

\section{TAX HAVEN CASE STUDIES}

The analysis above identifies examples of companies making use of tax havens. The corporate structures themselves range from simple to complex. Below we highlight the corporate structures of a series of companies in order to illustrate the ways in which subsidiaries in tax havens can be used.

Africa Oil Corp holds petroleum rights through three separate companies. The rights to Blocks 9, 10BB, 12A and 13T are routed through subsidiaries in the Netherlands. Rights to Block 10BA are held through the original Centric Energy corporate structure and are routed through subsidiaries in Barbados.

\section{PTT Public Company}

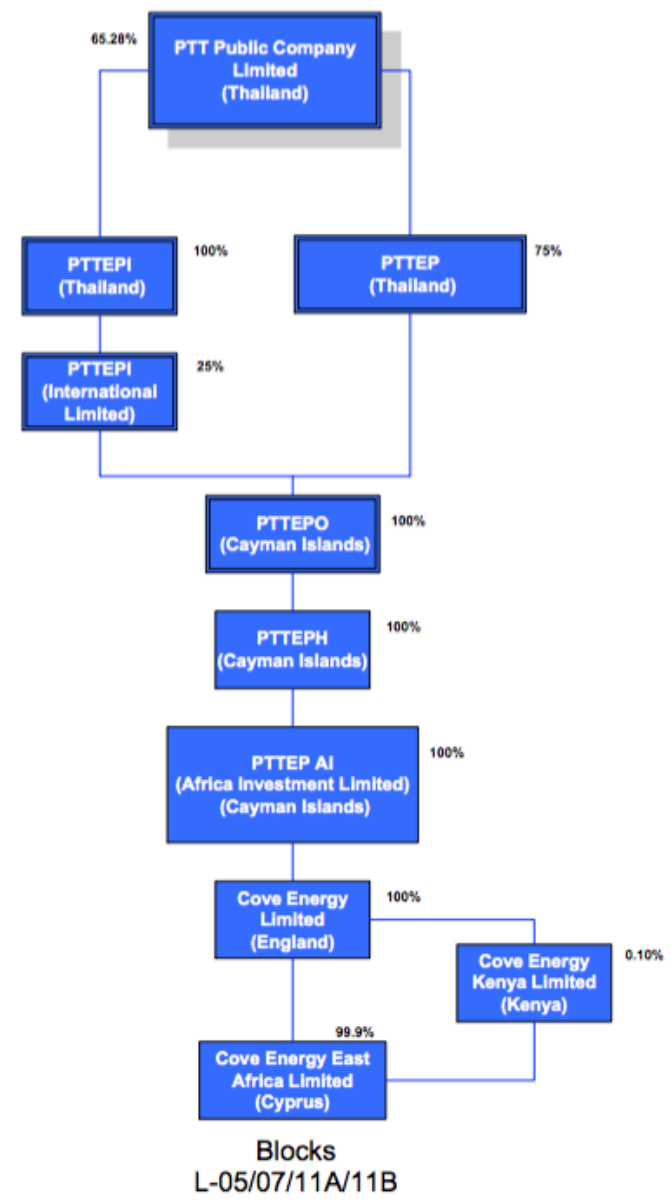

Africa Oil Corp.

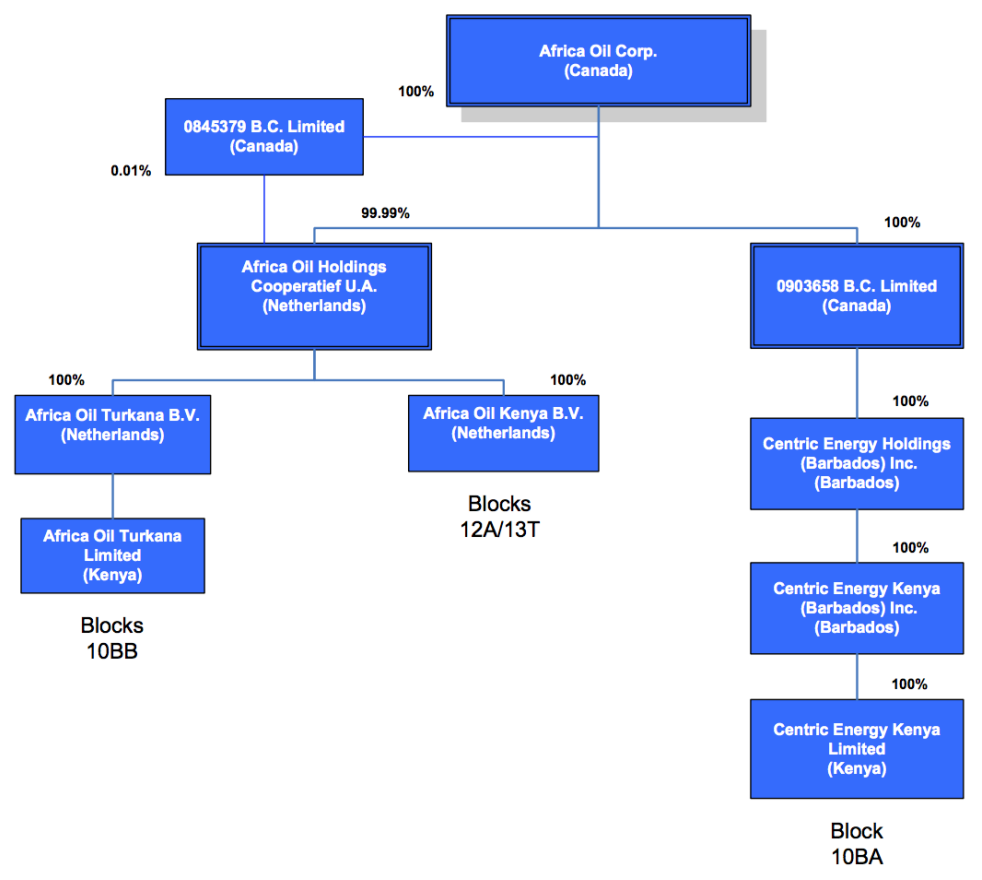

PTT Public Company, the state oil company of Thailand, has structured its ownership of petroleum rights to Blocks L05, L-07, L-11A, and L-11B through multiple subsidiaries registered in the Cayman Islands. The direct ownership of the rights retains the original Cove Energy corporate structure with a subsidiary in Cyprus. 


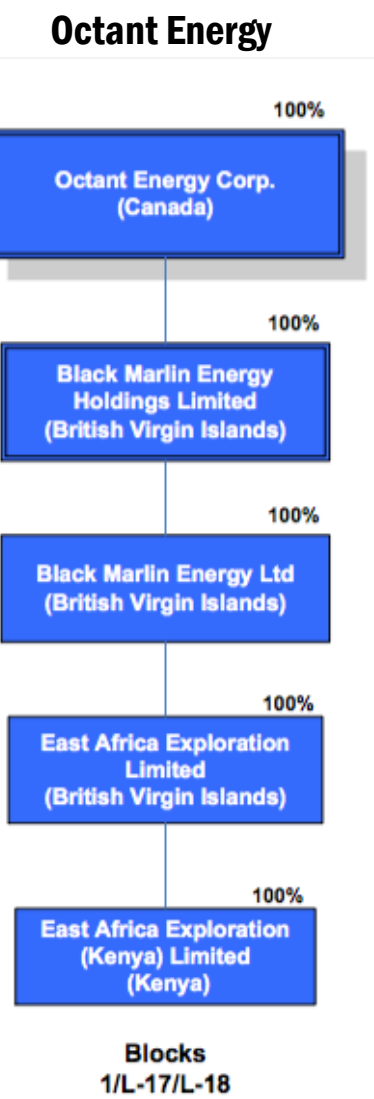

Octant Energy Corp. registered in Canada, recently bought the rights to Kenyan petroleum Blocks L1, L17 and L18 that had been held by Afren PIc, a UK listed company that has went bankrupt in July 2015. Afren's rights to the three blocks were acquired in 2010 when it purchased Canadian-listed Black Marlin Energy Holdings Limited, a company incorporated in the British Virgin Islands. Octant Energy retains the series of BVI subsidiaries leading to the Kenyan subsidiary named East Africa Exploration (Kenya) Limited (also know as EAX).

Swala Energy Ltd

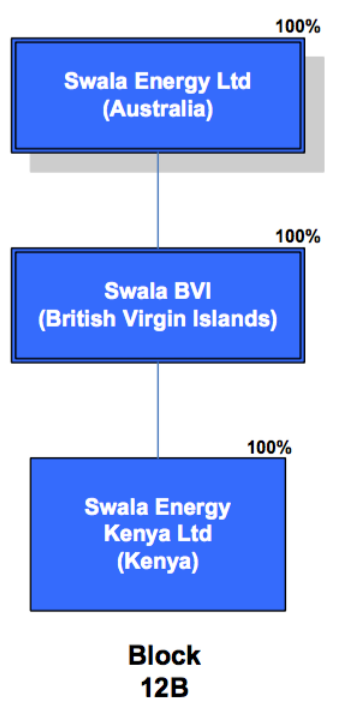

Ophir Energy PIc

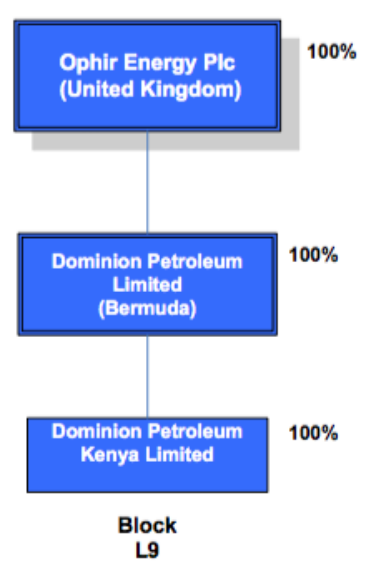

Vanoil Energy Ltd.

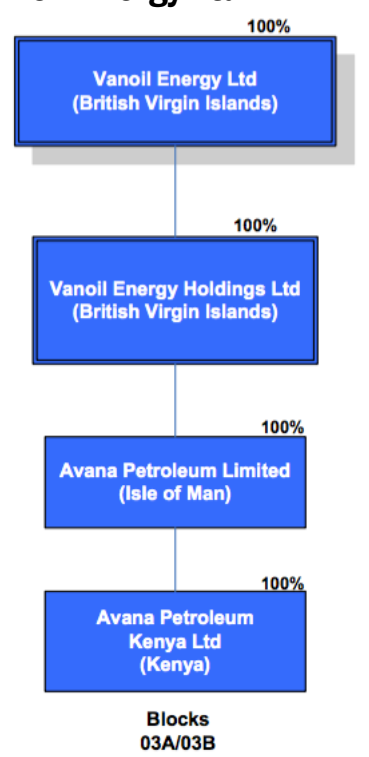


Swala Energy Ltd and Ophir Energy PIc are both publicly listed companies in OECD jurisdictions and have subsidiaries in classic tax havens that subsequently own Kenyan subsidiaries holding rights to blocks 12B and L9. Vanoil's corporate hierarchy starts in Canada, with subsidiaries in two separate tax havens leading to a final subsidiary in Kenya.

Rift Energy also starts in Canada and holds Kenya petroleum rights through two separate subsidiaries both registered in the tax haven of Bermuda. Midway Resources International is registered in the tax haven of the Cayman Islands while owning Kenyan petroleum rights through a subsidiary in another tax haven - Mauritius.
Rift Energy Corp.

Midway Resources

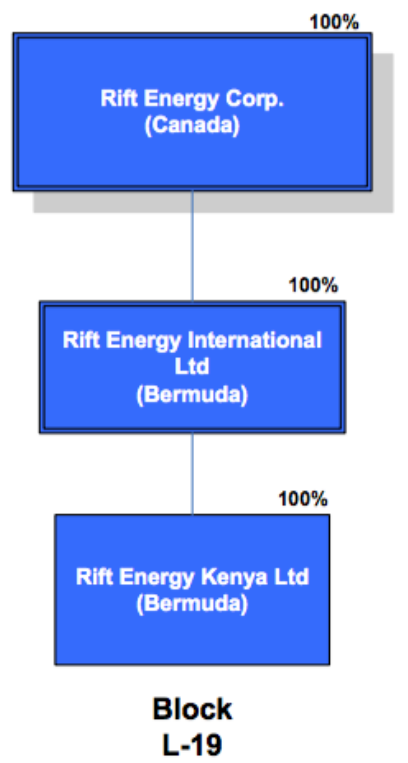

$100 \%$

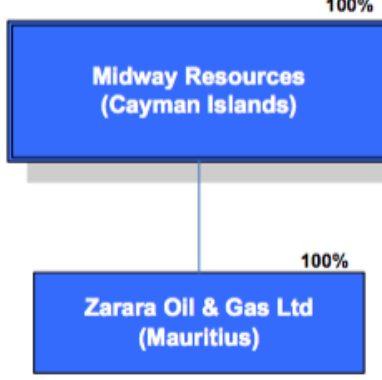

Blocks

L-13/L-04 


\section{CONCLUSIONS}

This analysis has demonstrated the widespread use of tax havens and low tax jurisdictions in the corporate structures of companies holding petroleum rights in Kenya. The thirty-five separate companies that hold a stake in an active petroleum license in Kenya are ultimately owned by twenty-seven parent companies. Seventeen parent companies own petroleum rights in Kenya directly through a subsidiary in a tax haven or low tax jurisdiction. Ultimately, all but five of the parent companies make use of a tax haven or low-tax jurisdiction as part of their wide corporate structure.

Oil companies commonly use subsidiaries in tax havens in order to minimize tax payments in both the countries in which they operate and the jurisdictions where they are headquartered. As Kenya is not yet a petroleum producing country, the risk to government revenues from the widespread use of subsidiaries in tax havens lies in the future rather than the present. Nevertheless, the government should to be alert to these risks as companies are incurring significant exploration expenses that will be recoverable if and when oil production begins. Care should be taken to review existing Double Taxation Agreements in order to ensure that benefits are not flowing to conduit companies that are not among the intended beneficiaries. Multinational oil companies should be required to publish financial results for each country where they have a presence (so-called country-by-country reporting). Kenyan subsidiaries should be required to publish their annual financial statements. This will greatly increase public transparency on potential profit shifting. While petroleum production is still some years away, priority should be given to building tax administration capacity in both the Ministry of Energy and Petroleum and in the Large Taxpayer Office of the Kenyan Revenue Agency.

Uncovering these corporate structures is much more difficult than should be the case. Best practice in extractive sector good governance calls for the government to publish details of all companies holding oil, gas and mineral rights. Kenya already provides some of this information through the online mining cadastre portal. Comprehensive information on petroleum rights should also be published including the legal names of operators and their joint venture partners as well as their respective percentage stakes and the dates on which the relevant transaction were concluded. Furthermore, as Kenya has made a public commitment to joining the EITI, companies should be required to disclose full details of their corporate structures and their beneficial owners. 
Annex 1: Listed Tax Havens

\begin{tabular}{|c|c|c|c|c|c|c|c|c|c|}
\hline JURISDICTION & IMF & US & EU & FSI & JURISDICTION & IMF & US & EU & FSI \\
\hline Andorra & $*$ & $*$ & $*$ & $*$ & Liberia & & & $*$ & $*$ \\
\hline Anguilla & $*$ & $*$ & $*$ & $*$ & Liechtenstein & $*$ & $*$ & $*$ & $*$ \\
\hline Antigua & $*$ & $*$ & $*$ & $*$ & Luxembourg & $*$ & $*$ & & $*$ \\
\hline Aruba & $*$ & $*$ & & $*$ & Macau & $*$ & & & $*$ \\
\hline Bahamas & $*$ & $*$ & $*$ & $*$ & $\begin{array}{l}\text { Malaysia } \\
\text { (Labuan) }\end{array}$ & $*$ & & & $*$ \\
\hline Barbados & $*$ & $*$ & $*$ & $*$ & Maldives & & & $*$ & $*$ \\
\hline Bahrain & $*$ & & & $*$ & Malta & $*$ & $*$ & & $*$ \\
\hline Belize & $*$ & $*$ & $*$ & $*$ & Marshall Islands & $*$ & & $*$ & $*$ \\
\hline Bermuda & $*$ & $*$ & $*$ & $*$ & Mauritius & $*$ & & $*$ & $*$ \\
\hline British Virgin IsI. & $*$ & $*$ & $*$ & $*$ & Monaco & $*$ & & $*$ & $*$ \\
\hline Brunei & $*$ & & $*$ & $*$ & Montserrat & $*$ & & $*$ & $*$ \\
\hline Cape Verde & $*$ & & & & Nauru & $*$ & $*$ & $*$ & $*$ \\
\hline Cook Islands & $*$ & $*$ & $*$ & $*$ & Niue & $*$ & & $*$ & $*$ \\
\hline Costa Rica & $*$ & $*$ & & $*$ & Panama & $*$ & $*$ & $*$ & $*$ \\
\hline Cyprus & $*$ & $*$ & & $*$ & Samoa & $*$ & $*$ & & $*$ \\
\hline Dominica & $*$ & $*$ & & $*$ & San Marino & $*$ & & & $*$ \\
\hline Dubai & $*$ & & & $*$ & Seychelles & $*$ & & $*$ & $*$ \\
\hline Gibraltar & $*$ & $*$ & & $*$ & Singapore & $*$ & $*$ & & $*$ \\
\hline Grenada & $*$ & $*$ & $*$ & $*$ & St. Kitts \& Nevis & $*$ & $*$ & $*$ & $*$ \\
\hline Guernsey & $*$ & $*$ & $*$ & $*$ & St. Lucia & $*$ & $*$ & & $*$ \\
\hline Hong Kong & $*$ & $*$ & $*$ & $*$ & $\begin{array}{l}\text { St. Vincent and } \\
\text { Grenadines }\end{array}$ & $*$ & $*$ & $*$ & $*$ \\
\hline Isle Of Man & $*$ & $*$ & & $*$ & Switzerland & $*$ & $*$ & & $*$ \\
\hline Ireland & $*$ & & & $*$ & $\begin{array}{l}\text { Turks \& Caicos } \\
\text { Isl. }\end{array}$ & $*$ & $*$ & $*$ & $*$ \\
\hline Jersey & $*$ & $*$ & & $*$ & Uruguay & $*$ & & & $*$ \\
\hline Latvia & & $*$ & & $*$ & $\begin{array}{l}\text { U.S. Virgin } \\
\text { Islands }\end{array}$ & & & $*$ & $*$ \\
\hline Lebanon & $*$ & & & $*$ & Vanuatu & $*$ & $*$ & $*$ & $*$ \\
\hline
\end{tabular}

Lists include OECD Harmful Tax Competition (2000), IMF Offshore Financial Centers (2007), US Stop Tax Havens Abuse Act 2015, EU Blacklist 2015, and Financial Secrecy Index (2015). Note that FSI also includes many other jurisdictions including Delaware, Netherlands, Switzerland and the United Kingdom (City of London). 
Annex II: Corporate Hierarchies and Ownership of Petroleum Rights

\begin{tabular}{|l|l|l|}
\hline Parent Company \& Subsidlaries & Jurisdiction & Ownership Stake \\
\hline Adamantine Energy LLC & Colorado & $\mathbf{1 0 0 \%}$ \\
\hline Adamantine Energy (Kenya) Limited & Kenya & \\
\hline Block 11B & \\
\hline
\end{tabular}

\begin{tabular}{|l|l|l|}
\hline Parent Company \& Subsidlaries & Jurisdiction & Ownership Stake \\
\hline Africa Oil Corp. & Canada & $\mathbf{1 0 0 \%}$ \\
\hline Africa Oil Holdings Cooperatief U.A. & Netherlands & $\mathbf{1 0 0 \%}$ \\
\hline Africa Oil Turkana B. V. & Netherlands & $\mathbf{1 0 0 \%}$ \\
\hline Africa Oil Turkana Ltd & Kenya & \\
\hline Block 09 \& 10BB & \\
\hline
\end{tabular}

\begin{tabular}{|l|l|l|}
\hline Parent Company \& Subsidlaries & Jurisdiction & Ownership Stake \\
\hline Africa Oil Corp. & Canada & $\mathbf{1 0 0} \%$ \\
\hline Africa Oil Holdings Cooperatief U.A. & Netherlands & $\mathbf{1 0 0 \%}$ \\
\hline Africa Oil Kenya BV & Netherlands & \\
\hline Block 12A \& 13T & \multicolumn{2}{|l}{} \\
\hline
\end{tabular}

\begin{tabular}{|l|l|l|}
\hline Parent Company \& Subsidlaries & Jurisdiction & Ownership Stake \\
\hline Africa Oil Corp. & Canada & $\mathbf{1 0 0 \%}$ \\
\hline 0903658 B.C. Ltd. & Canada & $\mathbf{1 0 0 \%}$ \\
\hline Centric Energy Holdings (Barbados) Inc. & Barbados & $\mathbf{1 0 0 \%}$ \\
\hline Centric Energy Kenya (Barbados) Inc. & Barbados & \\
\hline Block 10BA & \\
\hline
\end{tabular}

\begin{tabular}{|l|l|l|}
\hline Parent Company \& Subsidlaries & Jurisdiction & Ownership Stake \\
\hline Royal Dutch Shell PIc & United Kingdom & $\mathbf{1 0 0} \%$ \\
\hline BG Group PIc & United Kingdom & $\mathbf{1 0 0 \%}$ \\
\hline BG Energy Holdings Limited & United Kingdom & $\mathbf{1 0 0} \%$ \\
\hline BG International Limited & United Kingdom & $\mathbf{1 0 0 \%}$ \\
\hline BG Kenya L10A Limited & United Kingdom & $\mathbf{5 0 \%}$ \\
\hline BG Kenya Limited & United Kingdom & \\
\hline Block L10A & \\
\hline
\end{tabular}

\begin{tabular}{|l|l|l|}
\hline Parent Company \& Subsidiaries & Jurisdiction & Ownership Stake \\
\hline Royal Dutch Shell PIc & United Kingdom & $\mathbf{1 0 0 \%}$ \\
\hline BG Group PIc & United Kingdom & $\mathbf{1 0 0} \%$ \\
\hline BG Energy Holdings Limited & United Kingdom & $\mathbf{1 0 0 \%}$ \\
\hline BG International Limited & United Kingdom & $\mathbf{1 0 0 \%}$ \\
\hline BG Kenya L10B Limited & United Kingdom & $\mathbf{5 0 \%}$ \\
\hline BG Kenya Limited & United Kingdom & \\
\hline Block L10B & \multicolumn{2}{|l}{} \\
\hline
\end{tabular}




\begin{tabular}{|l|l|l|}
\hline Parent Company \& Subsidlaries & Jurisdiction & Ownership Stake \\
\hline Chicason Group Of Companies Nigeria Limited & Nigeria & $\mathbf{1 0 0} \%$ \\
\hline A-Z Petroleum Ltd & Nigeria & $\mathbf{1 0 0} \%$ \\
\hline A-Z Petroleum (Kenya) Limited & Kenya & \\
\hline Block L-01A \& L-03 & \\
\hline
\end{tabular}

\begin{tabular}{|l|l|l|}
\hline Parent Company and Subsidlarles & Jurisdiction & Ownership Stake \\
\hline Camac International Corp & Delaware & $100 \%$ \\
\hline Camac International Limited & Cayman Islands & $100 \%$ \\
\hline Camac Energy EP Limited & Cayman Islands & $100 \%$ \\
\hline CAMAC Energy Holdings Ltd. & Cayman Islands & $100 \%$ \\
\hline Erin Energy Corporation & Delaware & $100 \%$ \\
\hline CAMAC Energy Kenya Limited & Kenya & \\
\hline Block L-01B, L-16, L-27, L-28 & & \\
\hline
\end{tabular}

\begin{tabular}{|l|l|l|}
\hline Parent Company \& Subsidlaries & Jurisdiction & Ownership Stake \\
\hline Ophir Energy Plc & United Kingdom & $\mathbf{1 0 0} \%$ \\
\hline Dominion Petroleum Limited & Bermuda & $\mathbf{1 0 0} \%$ \\
\hline Dominion Petroleum Kenya Limited & Kenya & \\
\hline Block L-9 & \\
\hline
\end{tabular}

\begin{tabular}{|l|l|l|}
\hline Parent Company \& Subsidlaries & Jurisdiction & Ownership Stake \\
\hline ERHC Energy Inc. & Colorado & $\mathbf{1 0 0} \%$ \\
\hline ERHC AGC Profond Ltd & British Virgin Islands & $\mathbf{1 0 0} \%$ \\
\hline ERHC Energy Kenya Limited & Kenya & \\
\hline Block 11A & \\
\hline
\end{tabular}

\begin{tabular}{|l|l|l|}
\hline Parent Company \& Subsidiaries & Jurisdiction & Ownership Stake \\
\hline Eni SpA & Italy & $\mathbf{1 0 0 \%}$ \\
\hline Eni International BV & Netherlands & $\mathbf{1 0 0 \%}$ \\
\hline Eni Kenya BV & Kenya & \\
\hline Block L-21, L-24, L-24 & \\
\hline
\end{tabular}

\begin{tabular}{|l|l|l|}
\hline Parent Company \& Subsidlaries & Jurisdiction & Ownership Stake \\
\hline Edgo Ltd & United Kingdom & $\mathbf{1 0 0 \%}$ \\
\hline Edgo Energy Limited & United Kingdom & $\mathbf{5 0 \%}$ \\
\hline Lamu Oil \& Gas Limited & Kenya & \\
\hline Block L-14 & \\
\hline
\end{tabular}




\begin{tabular}{|l|l|l|}
\hline Parent Company \& Subsidlaries & Jurisdiction & Ownership Stake \\
\hline Qatar First Bank LLC & Qatar & $\mathbf{5 0 \%}$ \\
\hline Lamu Oil \& Gas Limited & Kenya & \\
\hline Block L-14 & \\
\hline
\end{tabular}

\begin{tabular}{|l|l|l|}
\hline Parent Company \& Subsidiaries & Jurisdiction & Ownership Stake \\
\hline Far Limited & Australia & $\mathbf{1 0 0 \%}$ \\
\hline Flow Energy Limited & Australia & \\
\hline Block L-6 & & \\
\hline
\end{tabular}

\begin{tabular}{|l|l|l|}
\hline Parent Company \& Subsidlaries & Jurisdiction & Ownership Stake \\
\hline Midway Resources International & Cayman Islands & $100 \%$ \\
\hline Zarara Oil \& Gas Ltd & Mauritius & $\mathbf{1 0 0 \%}$ \\
\hline Block L-04 \& L-13
\end{tabular}

\begin{tabular}{|l|l|l|}
\hline Parent Company \& Subsidlaries & Jurisdiction & Ownership Stake \\
\hline Milio International & Bahamas & $100 \%$ \\
\hline Milio E\&P Limited & Bahamas & $100 \%$ \\
\hline $\begin{array}{l}\text { Milio Exploration \& Production (Kenya) } \\
\text { Ltd }\end{array}$ & Kenya & \\
\hline Block L-06 (onshore) \& L20 & \\
\hline
\end{tabular}

\begin{tabular}{|l|l|l|}
\hline Parent Company \& Subsidlaries & Jurisdiction & Ownership Stake \\
\hline Maersk Olie og Gas A/S & Denmark & $\mathbf{1 0 0 \%}$ \\
\hline $\begin{array}{l}\text { Maersk Oil Exploration International } \\
\text { Ltd. }\end{array}$ & United Kingdom & $\mathbf{1 0 0 \%}$ \\
\hline $\begin{array}{l}\text { Maersk Oil Exploration International } \\
\text { K1 Limited }\end{array}$ & United Kingdom & \\
\hline Block 10BA & \\
\hline
\end{tabular}

\begin{tabular}{|l|l|l|}
\hline Parent Company \& Subsidlarles & Jurisdlction & Ownership Stake \\
\hline Maersk Olie og Gas A/S & Denmark & $100 \%$ \\
\hline $\begin{array}{l}\text { Maersk Oil Exploration International } \\
\text { Ltd. }\end{array}$ & United Kingdom & $100 \%$ \\
\hline $\begin{array}{l}\text { Maersk Oil Exploration International } \\
\text { K2 Limited }\end{array}$ & United Kingdom & \\
\hline Block 10BA & \\
\hline
\end{tabular}

\begin{tabular}{|l|l|l|}
\hline Parent Company \& Subsidlaries & Jurisdiction & Ownership Stake \\
\hline Maersk Olie og Gas A/S & Denmark & $\mathbf{1 0 0 \%}$ \\
\hline $\begin{array}{l}\text { Maersk Oil Exploration International } \\
\text { Ltd. }\end{array}$ & United Kingdom & $\mathbf{1 0 0 \%}$ \\
\hline $\begin{array}{l}\text { Maersk Oil Exploration International } \\
\text { K3 Limited }\end{array}$ & United Kingdom & \\
\hline Block 10BA & \\
\hline
\end{tabular}




\begin{tabular}{|l|l|l|}
\hline Parent Company \& Subsidlaries & Jurisdiction & Ownership Stake \\
\hline Octant Energy Corp. & Canada & $\mathbf{1 0 0 \%}$ \\
\hline Black Marlin Energy Holdings Limited & British Virgin Islands & $\mathbf{1 0 0} \%$ \\
\hline Black Marlin Energy Ltd & British Virgin Islands & $\mathbf{1 0 0} \%$ \\
\hline East Africa Exploration Limited & British Virgin Islands & $\mathbf{1 0 0} \%$ \\
\hline East Africa Exploration (Kenya) Limited & Kenya & \\
\hline Block 1 & \\
\hline
\end{tabular}

\begin{tabular}{|l|l|l|}
\hline Parent Company \& Subsidlaries & Jurisdiction & Ownership Stake \\
\hline Octant Energy Corp. & Canada & $100 \%$ \\
\hline Imara Energy Corp & Canada & \\
\hline Block L-2 & \\
\hline
\end{tabular}

\begin{tabular}{|l|l|l|}
\hline Parent Company \& Subsidlaries & Jurisdiction & Ownership Stake \\
\hline PTT Public Company Limited & Thailand & $\mathbf{6 5 . 2 8 6} \%$ \\
\hline PTTEP (Exploration \& Production) & Thailand & $\mathbf{7 5 \%}$ \\
\hline PTTEP0 (Offshore Investment Comp Ltd) & Cayman Islands & \\
\hline PTTEPI (International Limited) & Thailand & $\mathbf{1 0 0 \%}$ \\
\hline PTTEP0 (Offshore Investment Comp Ltd) & Cayman Islands & \\
\hline
\end{tabular}

\begin{tabular}{|l|l|l|}
\hline $\begin{array}{l}\text { PTTEP0 (Offshore Investment Company } \\
\text { Limited) }\end{array}$ & Cayman Islands & $\mathbf{1 0 0 \%}$ \\
\hline PTTEPH (Holding Company Limited) & Cayman Islands & $\mathbf{1 0 0 \%}$ \\
\hline PTTEP Al (Africa Investment Limited) & Cayman Islands & $\mathbf{1 0 0 \%}$ \\
\hline Cove Energy Limited & England & $\mathbf{1 0 0 \%}$ \\
\hline CEEAL (Cove Energy East Africa Limited) & Cyprus & $\mathbf{9 9 . 9 \%}$ \\
\hline Cove Energy Kenya Limited & Kenya & $\mathbf{1 0 0 \%}$ \\
\hline Block L-07, L11A,L-11B,L-12,L-05 & & \\
\hline Cove Energy Limited & England & $\mathbf{0 . 1 0 \%}$ \\
\hline Cove Energy Kenya Limited & Kenya & \\
\hline Block L-07, L11A, L-11B,L-12,L-05 & \multicolumn{2}{|l}{} \\
\hline
\end{tabular}

\begin{tabular}{|l|l|l|}
\hline Parent Company \& Subsidlaries & Jurisdiction & Ownership Stake \\
\hline Simba Energy Inc & British Columbia & $\mathbf{4 0 \%}$ \\
\hline Simba Africa Rift Energy Limited & Kenya & \\
\hline Block 02A & \\
\hline
\end{tabular}

\begin{tabular}{|l|l|l|}
\hline \hline Parent Company \& Subsidlaries & Jurisdlction & Ownership Stake \\
\hline Essel Group India & India & $\mathbf{1 0 0} \%$ \\
\hline Essel Group ME Limited & United Kingdom & $\mathbf{1 0 0} \%$ \\
\hline Simba Africa Rift Energy Limited & Kenya & $\mathbf{1 0 0} \%$ \\
\hline Block 02A & \\
\hline
\end{tabular}

\begin{tabular}{|l|l|l|}
\hline Parent Company \& Subsidlaries & Jurisdiction & Ownership Stake \\
\hline Total S.A. & France & $\mathbf{6 5 . 8} \%$ \\
\hline Total E\&P Holdings & France & $\mathbf{1 0 0 \%}$ \\
\hline Total E\&P Kenya BV & Netherlands & \\
\hline Block L-11A, L-11B, L-12, L-22 & \\
\hline
\end{tabular}




\begin{tabular}{|l|l|l|}
\hline Parent Company \& Subsidlarles & Jurlsdlctlon & Ownershlp Stake \\
\hline Total S.A. & France & $\mathbf{1 0 0 \%}$ \\
\hline Elf Aquitaine & France & $\mathbf{3 4 . 2} \%$ \\
\hline Total E\&P Holdings & France & $\mathbf{1 0 0 \%}$ \\
\hline Total E\&P Kenya BV & Netherlands & \\
\hline Block L-11A, L-11B, L-12, L-22 & \multicolumn{2}{|}{} \\
\hline
\end{tabular}

\begin{tabular}{|l|l|l|}
\hline Parent Company \& Subsidlaries & Jurisdlction & Ownership Stake \\
\hline Tullow Oil PIc & United Kingdom & $\mathbf{1 0 0 \%}$ \\
\hline Tullow Overseas Holdings BV & Netherlands & $\mathbf{1 0 0} \%$ \\
\hline Tullow Kenya BV & Netherlands & \\
\hline Block L-2 & \\
\hline
\end{tabular}

\begin{tabular}{|l|l|l|}
\hline Parent Company \& Subsidlaries & Jurisdiction & Ownership Stake \\
\hline Vanoil Energy Ltd. & British Virgin Islands & $\mathbf{1 0 0} \%$ \\
\hline Vanoil Energy Holdings Ltd. & British Virgin Islands & $\mathbf{1 0 0} \%$ \\
\hline Avana Petroleum Limited & Isle of Man & $\mathbf{1 0 0} \%$ \\
\hline Vanoil Energy Ltd. & British Virgin Islands & $\mathbf{1 0 0} \%$ \\
\hline Avana Petroleum Kenya Ltd. & Kenya & \\
\hline Block 03A, 3B & \multicolumn{2}{|l}{} \\
\hline
\end{tabular}

\begin{tabular}{|l|l|l|}
\hline Parent Company \& SubsIdlarles & Jurlsdlctlon & Ownershlp Stake \\
\hline Swiss0il Holdings International Ltd. & Mauritius & $100 \%$ \\
\hline SOHI Oil and Gas Limited & Mauritius & $100 \%$ \\
\hline Sohi Gas Dodori Ltd & Kenya & \\
\hline Block L-13 & \\
\hline
\end{tabular}

\begin{tabular}{|l|l|l|}
\hline Parent Company \& Subsidlaries & Jurisdiction & Ownership Stake \\
\hline SwissOil Holdings International Ltd. & Mauritius & $100 \%$ \\
\hline SOHI Oil and Gas Limited & Mauritius & $100 \%$ \\
\hline Sohi Gas Lamu Ltd & Kenya & \\
\hline Block L-04 & \\
\hline
\end{tabular}

\begin{tabular}{|l|l|l|}
\hline Parent Company \& Subsidlaries & Jurisdiction & Ownership Stake \\
\hline Rift Energy Corp. & Canada & $\mathbf{1 0 0 \%}$ \\
\hline Rift Energy International Ltd & Bermuda & $\mathbf{1 0 0 \%}$ \\
\hline Rift Energy Kenya Ltd & Bermuda & \\
\hline Block L-19 & \\
\hline
\end{tabular}




\begin{tabular}{|l|l|l|}
\hline Parent Company \& Subsidlaries & Jurisdlction & Ownership Stake \\
\hline Swala Energy Ltd & Australia & $100 \%$ \\
\hline Swala BVI & British Virgin Island & $100 \%$ \\
\hline Swala Energy Kenya Ltd- & Kenya & \\
\hline Block 12B & \\
\hline
\end{tabular}

\begin{tabular}{|l|l|l|}
\hline Parent Company \& Subsidlaries & Jurisdiction & Ownership Stake \\
\hline Taipan Resources Inc. & Canada & $100 \%$ \\
\hline Lion Petroleum & Canada & \\
\hline Block 1, 02B & \\
\hline
\end{tabular}


Insufficlent Data

\begin{tabular}{|l|l|l|}
\hline Parent Company \& Subsidlaries & Jurisdiction & Ownership Stake \\
\hline Anadarko Petroleum Corp & United States & \\
\hline Anadarko Kenya Company & Kenya & \\
\hline Block L-05, L-07 L-11A, L-11B, L-12 & & \\
\hline
\end{tabular}

\begin{tabular}{|l|l|l|}
\hline Parent Company \& Subsidlaries & Jurisdiction & Ownership Stake \\
\hline Compania Espanola De Petroleos & & \\
S.A.U. & Spain & \\
\hline CEPSA Kenya Ltd & Kenya & \\
\hline Block 11A & & \\
\hline
\end{tabular}




\section{NOTES}

${ }^{1}$ See for example, Track It, Stop It, Get It: Report of the High Level Panel on Illicit Financial Flows from Africa, 2014; Illicit Financial Flows from Africa: Hidden Resource for Development, Global Financial Integrity, 2010; and Exposing the lost billions: How financial transparency by multinationals on a country by country basis can aid development, Eurodad, 2011.

2 See "Chapter 5: International Tax and Investment Policy Coherence" in World Investment Report 2015, UNCTAD, 2015; and Jones \& Temouri, The determinants of Tax haven FDI.

${ }^{3}$ For the OECD see: Action Plan on Base Erosion and Profit Shifting, 2013, and Report To G20 Developing Working Group On The Impact Of BEPS In Low Income Countries, 2014; for the UN Financing for Development process see Foreign direct investment issues and corporate taxation, including resource taxation: issues for consideration by Committee (E/C.18/2013/5), 2013; see also How Tax Havens Plunder the Poor, Action Aid, 2013.

${ }^{4}$ See Piping Profits, Publish What You Pay - Norway, 2011.

5 See Cobham, Estimating Illicit Flows of Capital via Trade Mispricing: A Forensic Analysis of Data on Switzerland, 2014.

${ }^{6}$ See OpenCorporates

7 OECD, Harmful Tax Competition: An Emerging Global Issue, 1998

8 OECD 2010 Promoting Transparency And Exchange Of Information For Tax Purposes

9 IMF, Concept of Offshore Financial Centers: In Search of an Operational Definition

10 OECD, The Global Forum On Transparency And Exchange of Information for Tax Purposes

${ }^{11}$ Identifying Tax Havens and Offshore Financial Centres, Tax Justice Network, 2007. Tax Justice Network,

12 See Piping Profits.

${ }^{13}$ Scott Dyreng, Bradley Lindsey and Jacob Thornock, The Role Delaware Plays as a Domestic Tax Haven, Oxford Centre for Business Taxation, 2011.

${ }^{14}$ See Francis Weyzig, The Central Role of Dutch Financing Companies in Tax Avoidance strategies, 2007.

${ }^{15}$ In tax case, Mongolia is the mouse that roared, Reuters, 2013.

16 See: An Extractive Affair: How one Australian mining company's tax dealings are costing the world's poorest country millions, ActionAid, 2015. 
${ }^{17}$ See: Kenya to Strengthen Trade and Investment with Netherlands, National Treasury, July 2015. The treaty articles on dividend, interest and royalties contain a so-called main purpose test, which is a type of anti-abuse clause against treaty shopping. However, this type of clause might not apply to conduit investments that were already in place before the treaty was concluded.

${ }^{18}$ See Martin Heya, Commissioner of Petroleum Overview of the Oil and Gas Sector in Kenya, 22 January 2016. NAFFAC is the National Fossil Fuels Advisory Committee.

${ }^{19}$ See Africa Oil Corp Year End Report 2014

20 See Africa Oil Corp Year End Report 2014

${ }^{21}$ See Tullow Oil PIc Annual Report 2014. Tullow Kenya B.V although registered in the Netherlands migrated its "fiscal residence, central management and control of the company and its affairs" to the United Kingdom

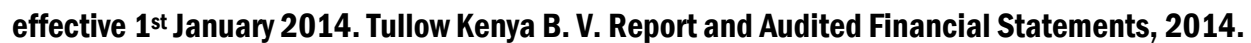

22 See Maersk Oil Farm Out Agreement, November 2015.

${ }^{23}$ See BG group PIc Annual Report 2014

${ }^{24}$ Deloitte Oil and Gas Taxation in Kenya

25 Deloitte Oil and Gas Taxation in Kenya

${ }^{26}$ See Octant Energy Corp Material Change

${ }^{27}$ Simba Energy Inc- News Release 3 December 2015.

${ }^{28}$ See Vanoil: 10 K

${ }^{29}$ See Vanoil: $10 \mathrm{~K}$

${ }^{30}$ See Africa Oil Corp - Year End Report 2014

31 See Tullow Oil PIc- Annual Report 2014

32 See Africa Oil Corp - Year End Report 2014

${ }^{33}$ See Maersk Oil Farm Out Agreement, November 2015.

${ }^{34}$ See Tullow Oil PIc Annual Report 2014

${ }^{35}$ See Africa Oil Corp Year End Report 2014

${ }^{36}$ See Maersk Oil Farm Out Agreement, November 2015.

37 See CEPSA - Annual Report 2014

${ }^{38}$ See ERHC Energy INC- Form $10 Q$

${ }^{39}$ See Bowleven Block 11B.

${ }^{40}$ Tullow Oil Plc- Annual Report 2014 
${ }^{41}$ Tullow Oil PIc- Annual Report 2014

42 See Farm Down Delonex Energy

${ }^{43}$ See Farm Down Delonex Energy

${ }^{44}$ See Tullow Oil PIc- Annual Report 2014

${ }^{45}$ Swala Energy - Report to Shareholders 2014

${ }^{46}$ See Tullow Oil PIc- Annual Report 2014

${ }^{47}$ Africa Oil Corp - Year End Report 2014

48 See Maersk Oil Farm Out Agreement, November 2015.

${ }^{49}$ A-Z Petroleum Itd Upstream Activities in Kenya

${ }^{50}$ Erin Energy Annual Report 2014

51 Imara Energy Kenya

52 A-Z Petroleum Ltd Upstream Activities in Kenya

${ }^{53}$ See Midway Resources International

${ }^{54}$ See Block L4

${ }^{55}$ See Exploration \& Production Kenya

56 See Exploration \& Production Kenya

${ }^{57}$ See Exploration \& Production Kenya

58 Milio E\&P Ltd Kenya

${ }^{59}$ Far Energy Limited: Annual Report 2014

60 Far Energy Limited: Annual Report 2014

61 See Exploration \& Production Kenya

62 See Ophir Annual Report 2014

63 See BG Group PIc- Annual Report 2014

${ }^{64}$ See BG Group PIc- Annual Report 2014

65 See Exploration \& Production Kenya

${ }^{66}$ See Exploration \& Production Kenya

67 See Exploration \& Production Kenya

68 See Midway Resources International

${ }^{69}$ Edgo Energy Ltd- Farm -in Opportunity

${ }^{70}$ See Erin Energy- Annual Report 2014 
${ }^{71}$ See Octant Energy Corp: Material Change

72 See Octant Energy Corp: Material Change

${ }^{73}$ Rift Energy-Farm-in Opportunity

74 Milio E\&P Ltd- Kenya

75 Milio E\&P Ltd- Farm-in Opportunity

${ }^{76}$ Eni SpA- Exploration \& Production Kenya

${ }^{77}$ Total S.A. - Exploration \& Production Kenya

78 Eni SpA- Exploration \& Production Kenya

${ }^{79}$ Eni SpA- Exploration \& Production Kenya

${ }^{80}$ See Erin Energy- Annual Report 2014

${ }^{81}$ See Erin Energy- Annual Report 2014

82 See Africa Oil Corp - Year End Report 2014

83 See Anadarko - List of Subsidiaries \& $\underline{\text { OpenCorporates }}$

${ }^{84}$ See CAMAC Energy - General Statement of Acquisition of Beneficial Ownership

${ }^{85}$ See Eni SpA- List of Subsidiaries

${ }^{86}$ See ERHC Energy INC- Form $10 Q$

87 Marathon Oil - Annual Report 2014

${ }^{88}$ See Midway Resources International

${ }^{89}$ See Milio E\&P Ltd- OpenCorporates

90 See Octant Energy Corp: OpenCorporates

${ }^{91}$ See Ophir Annual Report 2014

${ }^{92}$ See PTTEP: List of Subsidiaries

93 See Rift Energy Corp OpenCorporates

${ }^{94}$ Swiss0il Holdings International Ltd: OpenCorporates

${ }^{95}$ Swala Energy - Report to Shareholders 2014

${ }^{96}$ Total S.A. -Consolidated Scope 2014

97 See Tullow Oil PIc- Annual Report 2014

${ }^{98}$ See Vanoil: $10 \mathrm{~K}$

${ }^{99}$ See Ophir Energy Plc, Annual Report and Accounts, 2014, p. 125. The companies refers the use of the two subsidiaries to manage intra- firm financing.

100 See Action 8-10, OECD BEPS Package 